\title{
Pengaruh Tingkat Pendidikan dan Pembagian Kerja Terhadap Prestasi Kerja Karyawan Pada PT Pos Indonesia (Persero) Palembang
}

\author{
Erfan Robyardi \\ Jurusan Manajemen, Fakultas Ekonomi, Universitas PGRI Palembang
}

\begin{abstract}
ABSTRAK
Sumber Daya Manusia merupakan unsur terpenting dan paling menentukan bagi kelancaran jalannya proses dalam pencapaian prestasi kerja. Manusia yang unggul adalah manusia yang selalu memperhatikan kehidupanya semenjak dia dilahirkan. Hari demi hari terus dilalui sampailah pada usia manusia mengenyam tingkat pendidikan, itupun merupakan dorongan dari diri mereka sendiri untuk menambah ilmu pengetahuan mereka. Manajemen, maka hal-hal yang berhubungan dengan motivasi perlu mendapat perhatian yang sungguh-sungguh dari setiap pimpinan guna keberhasilan suatu organisasi. Metode analisis yang digunakan adalah analisis kuantitatif. Populasi dalam penelitian ini yaitu karyawan pada PT Pos Indonesia (Persero) Palembang. Populasi berjumlah 54 responden. Nilai koefisien determinasi $\left(\mathrm{R}^{2}\right)$ sebesar $63 \%$ yang artinya bahwa naik turunnya Prestasi Kerja pegawai pada PT Pos Indonesia (Persero) Palembang dapat dijelaskan oleh kontribusi Tingkat Pendidikan dan Pembagian Kerja sebesar $63 \%$, sedangkan sisanya $37 \%$ dijelaskan oleh variabel lain yang tidak dimasukan dalam penelitian ini. Terdapat pengaruh positif dan signifikan antara Tinkat Pendidikan terhadap Prestasi Kerja pegawai, diperoleh nilai thitung $=5,303=$ lebih besar dari nilai $t_{\text {tabel }}=2,007$. yang berarti $\mathrm{H}_{a}$ diterima dan $\mathrm{H}_{0}$ ditolak. Terdapat pengaruh positif dan signifikan antara Pembagian Kerja terhadap Prestasi Kerja Pegawai, diperoleh nilai thitung $=6,370$ lebih besar dari nilai $t_{\text {tabel }}=2,007$.
\end{abstract}

Kata Kunci : Pengaruh Tingkat Pendidikan, Pembagian Kerja, Prestasi Kerja

\section{A. PENDAHULUAN}

Sumber Daya Manusia merupakan unsur terpenting dan paling menentukan bagi kelancaran jalannya proses dalam pencapaian prestasi kerja. Manusia yang unggul adalah manusia yang selalu memperhatikan kehidupanya semenjak dia dilahirkan. Pada awalnya manusia dilahirkan dimuka bumi ini dalam keadaan polos tanpa ada satu benangpun yang menempel pada tubuh mereka. Manusia yang baru dilahirkan ini belum memiliki kemampuan untuk berbicara, berdiri, berjalan dan melakukan suatu kegiatan. Gerakan mulai dari hal - hal yang sederhana baru mereka bisa lakukan, seperti menangis, tersenyum, tertawa, membalikkan tubuh ke kanan maupun ke kiri, merangkak, minum dan makan masih disuapin, buang air kecil dan buang air besar.

Hari demi hari terus dilalui sampailah pada usia manusia mengenyam tingkat pendidikan, itupun merupakan dorongan dari diri mereka sendiri untuk menambah ilmu pengetahuan mereka. Ini disebabkan melihat teman - teman sebaya sudah memiliki ilmu pengetahuan yang lebih dari dirinya sendiri, oleh karena itu ada keinginan untuk mengikuti pendidikan yang nantinya dapat menolong mereka didalam melakukan aktivitas kehidupan sehari hari. Tingkat pendidikan yang ada di Indonesia

Manajemen, maka hal-hal yang berhubungan dengan motivasi perlu mendapat perhatian yang sungguhsungguh dari setiap pimpinan guna keberhasilan suatu organisasi. Apabila 
motivasi tersebut diiringi dengan kemampuan yang dimiliki karyawan dalam melaksanakan pekerjaannya, maka karyawan tersebut diharapkan dapat digerakkan, diorganisir, diarahkan, diawasi dan mengarahkan segala sumber daya yang dimilikinya untuk mengoptimalkan prestasi kerjanya.

\section{B. KAJIAN TEORI}

1. Pengertian Tingkat Pendidikan Menurut UU RI No. 20 Tahun 2003 pasal 3 Pendidikan bertujuan untuk "Mencerdaskan kehidupan bangsa dan mengembangkan manusia Indonesia seutuhnya, yaitu manusia yang beriman dan bertaqwa kepada Tuhan Yang Maha Esa dan berbudi pekerti luhur, memiliki pengetahuan dan ketrampilan, kesehatan jasmani dan rohani, kepribadian yang mantap dan bertanggung jawab kemasyarakatan dan kebangsaan". Untuk mencapai tujuan tersebut, pendidikan diselenggarakan melalui jalur pendidikan sekolah (pendidikan formal) dan jalur pendidikan luar sekolah (pendidikan non formal). Jalur pendidikan sekolah (pendidikan formal) $t$ erdapat jenjang pendidikan sekolah, jenjang pendidikan sekolah pada dasarnya terdiri dari pendidikan prasekolah, pendi dikan dasar, pendidikan menengah, dan pendidikan tinggi.

Menurut Lestari (2011:24) Tingkat Pendidikan merupakan suatu kegiatan seseorang dalam mengembangkan kemampuan, sikap, dan bentuk tingkah lakunya, baik untuk kehidupan masa kini dan sekaligus persiapan bagi kehidupan masa yang akan datang dimana melalui organisasi tertentu ataupun tidak terorganisir.
Adapun indikator Tingkat Pendidikan menurut Lestari (2011:24) adalah sebagai berikut :

$>$ Pendidikan Formal

$>$ Pendidikan Nonformal

$>$ Pendidikan Informal

2. Pengertian Pembagian Kerja

Menurut Ardana dkk (2012:82) Pembagian kerja adalah suatu proses pemberian tugas dan pekerjaan yang lulus dalam seleksi untuk dilaksanakan secara continue dan wewenang serta tanggung jawab yang melekat sebesar porsi dan komposisi yang di tetapkan serta mampu mempertanggungjawabkan segala risiko yang mungkin terjadi atas tugas dan pekerjaan, wewenang dan tanggung jawab tersebut. Dari definisi tentang pembagian kerja diatas dapat disimpulkan bahwa pembagian kerja adalah proses penempatan yang dilakukan oleh perusahaan dengan memperhatikan kwalitas tingkat pendidikan dan kemampuan yang dimiliki oleh karyawan itu sendiri sesuai dengan tempat yang akan ditempatkan pada karyawan tersebut.

Menurut Ardana dkk (2012:94) Untuk mengukur pembagian kerja digunakan indikator-indikator sebagai berikut :
a) Penempatan Pegawai
Penempatan pegawai ialah bahwa setiap pegawai telah ditempatkan sesuai dengan kemampuan, keahlian dan pendidikan yang dimiliki sebab ketidakpastian dalam menetapkan pekerjaan menjadi kurang lancar dan tidak maksimal
b) Beban Kerja
Beban kerja adalah tugas pekerjaan yang dipercayakan untuk dikerjakan dan 
dipertanggungjawabkan oleh satuan organisasi atau seorang pegawai tertentu.

Beban kerja yang harus dilaksanakan pegawai hendaknya merata, sehingga dapat dihindarkan adanya seorang pegawai yang mempunyai beban kerja yang berlebihan dan yang terlalu sedikit.

c) Spesialisasi Pekerjaan

Spesialisasi pekerjaan adalah pembagian kerja berdasarkan keahlian dan keterampilan khusus. Spesialisasi pekerjaan sangat diperlukan dalam setiap organisasi karena tidak semua pekerjaan membutuhkan keahlian dan tidak semua orang mempunyai keahlian yang sama sebab setiap orang mempunyai kelebihan dan keterbatasan sendiri.

3. Pengertian Prestasi Kerja

Menurut Sutrisno (2014:128)

Prestasi kerja merupakan sebagai hasil kerja yang telah dicapai seseorang dari tingkah laku kerjanya dalam melaksanakan aktivitas kerja

Adapun indikator prestasi kerja menurut Sutrisno (2014:152) sebagai berikut:

a) Hasil Kerja

Tingkat kuantitas maupun kualitas yang telah dihasilkan dan sejauh mana pengawasan dilakukan.

b) Kedisiplinan

Tingkat ketepatan waktu dan tingkat kehadiran. Selalu mentaati peraturan yang berlaku dalam organisasi atau perusahaan. c) Tanggung Jawab

Bertanggung jawab terhadap apa yang diberikan atau dibebankan kepada karyawan oleh perusahaan, dan siap menerima resiko apapun dalam tanggung jawab pekerjaan.

\section{METODOLOGI PENELITIAN}

1) Variabel Penelitian

Menurut Sugiyono (2015:39)

Variabel penelitian adalah segala sesuatu yang berbentuk apa saja yang ditetapkan oleh peneliti untuk dipelajari sehingga diperoleh informasi tentang hal tersebut, kemudian ditarik kesimpulannya.

Variable - variable yang digunakan Pada penelitian ini adalah sebagai berikut:

a) Variabel bebas (Variabel Independen )

Variabel bebas merupakan merupakan variabel yang mempengaruhi atau yang menjadi sebab perubahannya atau timbulnya variabel dependen (terikat). Varibel bebas (X) dalam penelitian ini adalah Tingkat Pendidikan (X1) dan Pembagian Kerja (X2)

b) Variabel terikat (Variabel Dependen)

Variabel terikat merupakan variabel yang dipengaruhi atau yang menjadi akibat, karena adanya variabel bebas. Variabel terikat (Y) dalam penelitian ini adalah Prestasi Kerja Karyawan (Y). 
2) Definisi Opersional Variabel

Definisi Operasional Variabel

\begin{tabular}{|c|c|c|c|c|}
\hline No & Variabel & Definisi & Indikator & Skala \\
\hline 1 & $\begin{array}{l}\text { Tingkat } \\
\text { Pendidikan } \\
\text { (X1) }\end{array}$ & $\begin{array}{l}\text { Tingkat Pendidikan merupakan } \\
\text { suatu kegiatan seseorang dalam } \\
\text { mengembangkan kemampuan, } \\
\text { sikap, dan bentuk tingkah lakunya, } \\
\text { baik untuk kehidupan masa kini } \\
\text { dan sekaligus persiapan bagi } \\
\text { kehidupan masa yang akan } \\
\text { datang dimana melalui organisasi } \\
\text { tertentu ataupun tidak terorganisir. } \\
\text { (Lestari, 2011:24) }\end{array}$ & 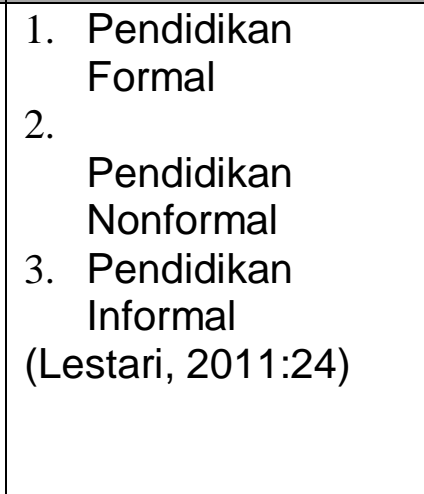 & Ordinal \\
\hline 2 & $\begin{array}{l}\text { Pembagian } \\
\text { Kerja (X2) }\end{array}$ & $\begin{array}{l}\text { Menurut Ardana dkk (2012:82) } \\
\text { Pembagian kerja adalah suatu } \\
\text { proses pemberian tugas dan } \\
\text { pekerjaan yang lulus dalam seleksi } \\
\text { untuk dilaksanakan secara } \\
\text { continue dan wewenang serta } \\
\text { tanggung jawab yang melekat } \\
\text { sebesar porsi dan komposisi yang } \\
\text { ditetapkan serta mampu } \\
\text { mempertanggungawabkan segala } \\
\text { risiko yang mungkin terjadi atas } \\
\text { tugas dan pekerjaan, wewenang } \\
\text { dan tanggung jawab tersebut. Dari } \\
\text { definisi tentang pembagian kerja } \\
\text { diatas dapat disimpulkan bahwa } \\
\text { pembagian kerja adalah proses } \\
\text { penempatan yang dilakukan oleh } \\
\text { perusahaan dengan } \\
\text { memperhatikan kwalitas tingkat } \\
\text { pendidikan dan kemampuan yang } \\
\text { dimiliki oleh karyawan itu sendiri } \\
\text { sesuai dengan tempat yang akan } \\
\text { ditempatkan pada karyawan } \\
\text { tersebut.(Ardana dkk, 2012:82) }\end{array}$ & $\begin{array}{l}\text { 1. Penempatan } \\
\text { Pegawai } \\
\text { 2. Beban Kerja } \\
\text { 3. Spesialisasi Peke } \\
\text { rjaan } \\
\text { (Ardana dkk, } \\
\text { 2012:82) }\end{array}$ & Ordinal \\
\hline 3 & $\begin{array}{l}\text { Prestasi } \\
\text { Kerja (Y) }\end{array}$ & $\begin{array}{l}\text { Prestasi kerja } \\
\text { merupakan sebagai hasil kerja } \\
\text { yang telah dicapai seseorang dari } \\
\text { tingkah laku kerjanya dalam } \\
\text { melaksanakan aktivitas kerja. } \\
\text { (Sutrisno, 2014:152) }\end{array}$ & 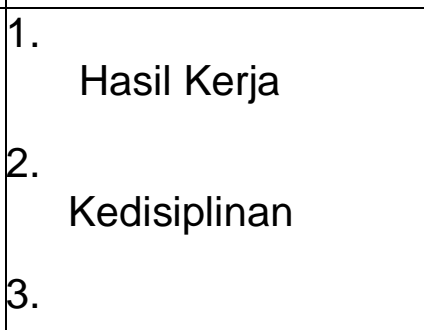 & Ordinal \\
\hline
\end{tabular}




\begin{tabular}{|l|l|l|c|l|}
\hline & & Tanggung Jawab & \\
(Sutrisno, 2014:152). & \\
\hline
\end{tabular}

D. POPULASI DAN SAMPEL

Populasi dalam penelitian ini adalah seluruh karyawan pada PT Pos Indonesia (Persero) Palembang.

Sampel Menurut Sugiyono (2014:91) sampel adalah bagian dari jumlah dan karakteristik yang dimiliki oleh populasi tersebut. Bila populasi besar, dan peneliti tidak mungkin mempelajari semua yang ada pada populasi, misalnya karena keterbatasan dana, tenaga dan waktu, maka peneliti dapat menggunakan sampel yang diambil dari populasi itu. Sampel yang diambil dalam penelitian ini adalah seluruh karyawan pada PT Pos Indonesia (Persero) Palembang.

\section{E. TEKNIK PENGUMPULAN DATA}

1. Observasi

Adalah suatu proses kompleks, tersusun dari berbagai proses biologis dan psikologis. Dua diantara yang terpenting adalah proses-proses pengamatan dan ingatan.

2. Kuisioner (angket)

Adalah teknik pengumpulan data yang dilakuakn dengan memberikan seperangkat pertanyaan yang di isi oleh responden.

\section{F. TEKNIK ANALISIS DATA}

1. Regresi Linier Sederhana Pengaruh Tingkat pendidikan dan Pembagian kerja terhadap Prestasi kerja karyawan Pada PT Pos Indonesia (Persero) Palembang akan dianalisis dengan menggunakan regresi linier sederhana $\mathrm{Y}=\mathrm{a}+\mathrm{bX}$

2. Koefisien Korelasi

Rumus Koefisien Korelasi

$$
r_{x y}=\frac{n\left(\sum x y\right)-\left(\sum x\right) \cdot\left(\sum y\right)}{\sqrt{\left(n \sum x^{2}-\left(\sum x\right)^{2}\left[\left(n x y^{2}-\left(\sum y\right)^{2}\right]\right.\right.}}
$$

3. Koefisien Determinasi

Koefisien Determinasi Dicari Menggunakan rumus

$$
\mathrm{KP}=\mathrm{r}^{2} \times 100 \%
$$

4. Uji t

Rumus uji t dicari menggunakan rumus :

$$
\text { thitung }=\frac{r_{p} \sqrt{n-3}}{\sqrt{1-r p^{2}}}
$$

\section{G. HASIL PENELITIAN DAN PEMBAHASAN}

1. Hasil Uji Reliabilitas 54 sampel

Hasil Uji Reliabilitas Instrumen

\begin{tabular}{|c|l|c|c|}
\hline No & \multicolumn{1}{|c|}{ Variabel } & Cronbach Alpha & Keterangan \\
\hline 1. & Tingkat Pendidikan & 0,794 & Reliabel \\
\hline 2. & Pembagian Kerja & 0,717 & Reliabel \\
\hline 3. & Prestasi Kerja & 0,670 & Reliabel \\
\hline
\end{tabular}


Hasil uji reliabilitas tersebut menunjukkan bahwa semua variabel mempunyai Cronbach Alpha yang besar, yaitu lebih dari 0,60. Sehingga dapat disimpulkan bahwa item-item 2. Hasil Analisis Koefisien Determinasi $\left(\mathrm{R}^{2}\right)$ pengukur variabel dari kuesioner adalah reliabel yang berarti bahwa hubungan antara Tingkat Pendidikan (X1), Pembagian Kerja (X2) Terhadap Prestasi Kerja (Y) adalah kuat

Analisis Koefisien Determinasi

Model Summary

\begin{tabular}{|l|r|r|r|r|}
\hline Model & $\mathrm{R}$ & $\mathrm{R}$ Square & $\begin{array}{c}\text { Adjusted R } \\
\text { Square }\end{array}$ & $\begin{array}{c}\text { Std. Error of } \\
\text { the Estimate }\end{array}$ \\
\hline 1 &, $813^{\mathrm{a}}$ &, 630 &, 609 & 1,817 \\
\hline
\end{tabular}

a. Predictors: (Constant), Pembagian Kerja, Tingkat Pendidikan

Dari tabel diatas diketahui bahwa nilai koefisien determinasi (Adjust $R$ Square) sebesar 0,630 atau $63 \%$. Artinya kontribusi sumbangan pengaruh Tingkat Pendidikan $\left(\mathrm{X}_{1}\right)$ dan Pembagian
$\operatorname{Kerja}\left(\mathrm{X}_{2}\right)$ terhadap Prestasi Kerja $(\mathrm{Y})$ sebesar $63 \%$ dan sisanya $37 \%$ dipengaruhi oleh faktor-faktor lain yang tidak diteliti.

3. Hasil Uji t

Hasil Uji t

Coefficients $^{a}$

\begin{tabular}{|c|c|c|c|c|c|}
\hline \multirow[b]{2}{*}{ Model } & \multicolumn{2}{|c|}{$\begin{array}{l}\text { Unstandardized } \\
\text { Coefficients }\end{array}$} & \multirow{2}{*}{$\begin{array}{c}\text { Standardized } \\
\text { Coefficients } \\
\text { Beta }\end{array}$} & \multirow[b]{2}{*}{$\mathrm{T}$} & \multirow[b]{2}{*}{ Sig. } \\
\hline & $B$ & Std. Error & & & \\
\hline (Constant) & ,681 & 4,173 & & , 4.375 &, 000 \\
\hline Tingkat Pendidikan & ,473 & , 154 & ,457 & 5,303 & ,000 \\
\hline Pembagian Kerja & ,562 &, 172 &, 521 & 6,370 &, 000 \\
\hline
\end{tabular}

a) Hasil uji untuk variabel $X_{1}$ (Tingkat Pendidikan) diperoleh nilai $t_{\text {hitung }}=$ 5,303 dengan taraf signifikansi 0,000. Dengan menggunakan batas 0,05 didapat tabel sebesar 2,007 (df = n-k-1 = 54-2-1 = 51). Ini berarti $t_{\text {hitung }}>t_{\text {tabel }}=5,303>2,007$ yang berarti $\mathrm{Ha}$ diterima dan $\mathrm{Ho}$ ditolak. Dengan demikian berarti bahwa Tingkat Pendidikan secara parsial berpengaruh signifikan terhadap Prestasi Kerja.

b) Hasil uji untuk variabel $X_{2}$ (Pembagian Kerja) diperoleh nilai thitung $=6,370$ dengan taraf signifikansi 0,002. Dengan menggunakan batas 0,05 didapat $t_{\text {tabel }}$ sebesar 2,007 ( $\mathrm{df}=\mathrm{n}-\mathrm{k}-1=$ $54-2-1=51)$. Ini berarti thitung $>t_{\text {tabel }}$ $=6,370>2,007$ yang berarti $\mathrm{Ha}$ diterima dan Ho ditolak. Dengan 
demikian berarti bahwa secara parsial Pembagian Kerja berpengaruh signifikan tarhadap Prestasi Kerja.

\section{H. Kesimpulan}

Berdasarkan hasil penelitian dan pembahasan yang telah di uraikan maka dapat disimpulkan bahwa Pengaruh Tingkat Pendidikan dan Pembagian Kerjat Terhadap Prestasi Kerja Pada PT Pos Indonesia (Persero) Palembang adalah sebagai berikut :

1. Nilai koefisien determinasi $\left(R^{2}\right)$ sebesar $63 \%$ yang artinya bahwa naik turunnya Prestasi Kerja pegawai pada PT Pos Indonesia (Persero) Palembang dapat dijelaskan oleh kontribusi Tingkat Pendidikan dan Pembagian Kerja sebesar $63 \%$, sedangkan sisanya $37 \%$ dijelaskan oleh variabel lain yang tidak dimasukan dalam penelitian ini.

2. Terdapat pengaruh positif dan signifikan antara Tinkat Pendidikan terhadap Prestasi Kerja pegawai, diperoleh nilai $t_{\text {hitung }}=5,303=$ lebih besar dari nilai $t_{\text {tabel }}=2,007$. yang berarti $\mathrm{H}_{\mathrm{a}}$ diterima dan $\mathrm{H}_{\mathrm{o}}$ ditolak.

3. Terdapat pengaruh positif dan signifikan antara Pembagian Kerja terhadap Prestasi Kerja Pegawai, diperoleh nilai thitung $=6,370$ lebih besar dari nilai $t_{\text {tabel }}=2,007$

\section{DAFTAR PUSTAKA}

Lestari, Widi. 2011. Pengantar Manajemen Umum. Alfabeta: Bandung.

Ardana, I, Komang. 2012. Manajemen Sumber Daya Manusia. Graha IImu:Yogyakarta.

Sutrisno, 2010. Manajemen Sumber Daya Manusia. Kencana: Jakarta.

Sugiono. 2016. Statistika Untuk Penelitian, Bandung: Alfabeta. 